Павелко О. В., к.е.н., доцент (Національний університет водного господарства та природокористування, м. Рівне)

\title{
ФАКТОРНИЙ АНАЛІЗ ФІНАНСОВИХ РЕЗУЛЬТАТІВ ДІЯЛЬНОСТІ БУДІВЕЛЬНИХ ПІДПРИЕМСТВ: МЕТОДИКА ТА ОСОБЛИВОСТІ ПРОВЕДЕННЯ
}

У статті досліджено сутність факторного аналізу та його види. Ідентифіковано та прокласифіковано фактори впливу на формування прибутку будівельних підприємств. Виконано факторний аналіз валового прибутку та прибутку операційної діяльності ТзОВ «Реноме-Євробуд» за 2014-2018 pp. методом ланцюгових підстановок та відносних різниць. Запропоновано факторні моделі, і встановлено вплив факторів на результуючі показники. Проведено факторний аналіз чистого прибутку ПП «Рівнеспецбуд» за 2015-2018 рр. методом ланцюгових підстановок, охарактеризовано результати факторного аналізу. Окреслено чинники зростання чистого прибутку будівельних підприємств. Здійснено критичний аналіз думок вчених-аналітиків щодо сутності собівартості будівельно-монтажних робіт. Охарактеризовано напрями їі мінімізації.

Ключові слова: економічний аналіз; факторний аналіз; фінансові результати; методи факторного аналізу; будівельні підприємства; прибуток.

Актуальність теми. Кожен господарюючий суб'єкт функціонує задля максимізації фінансових результатів господарської діяльності у стратегічній перспективі. Величина позитивного фінансового результату ілюструє стабільний розвиток, ефективне господарювання і $€$ основним чинником формування фінансових ресурсів підприємства. Фінансові результати $є$ одним із ключових об'єктів наукових досліджень у сфері економіки, а визначення їх сутності в загальноекономічному аспекті передбачає узгодження характеру співвідношення доходів звітного періоду зі здійсненими витратами.

Як влучно констатує Т.С. Осадча, «..показники фінансових результатів характеризують абсолютну ефективність господарювання підприємства і стають найважливішими для оцінки його виробничої та фінансової діяльності» [1, С. 108].

Прибуток безперечно є: фактором розвитку і наслідком будьякого виробництва, метою створення і функціонування підприємства, генератором виробничого процесу, джерелом забезпечення внутрішніх потреб підприємства; основним показником успішної діяльності підприємства; фінансовим результатом діяльності 168 
господарюючого суб'єкта, що одержаний при співпраці 3 контрагентами внаслідок використання знань, вмінь та навичок працівників, коли дохід перевищує витрати.

Задля оцінки ефективності ведення господарської діяльності будівельних підприємств недостатнім $€$ аналіз виключно величини прибутку за досліджуваний період. Важливим $\epsilon$ дослідження динаміки прибутку з урахуванням дії низки факторів. Саме за результатами факторного аналізу виникає можливість оцінки якості фінансового результату, яка в свою чергу вважається достатньо високою, якщо величина фінансового результату обумовлена зростанням чистого доходу, зменшенням собівартості. Натомість низька якість фінансового результату характеризується зростанням обсягів реалізації за рахунок росту цін на продукцію без збільшення фізичного обсягу продажів і зниження витрат на гривню продукції [2]. Максимізації прибутку будівельних підприємств можливо досягнути за рахунок:

- нарощування обсягів виконання будівельних робіт;

- вжиття заходів, спрямованих на підвищення продуктивності праці;

- зменшення собівартості виконання будівельних робіт;

- проведення виваженої, кваліфікованої цінової політики;

- вдалої, раціональної побудови договірних відносин 3 контрагентами (постачальниками будівельних матеріалів, підрядниками, замовниками тощо);

- застосування маркетингу, зокрема перманентного проведення дослідження ринку, поведінки конкурентів, замовників, інвесторів тощо.

Аналіз останніх досліджень і публікацій. Проблеми економічної сутності та аналізу фінансових результатів висвітлено в працях сучасних вітчизняних науковців: І. Ю. Єпіфанової,
І. В. Жиглей,
Н. А. Іщенко,
Т. С. Осадчої,
Г.І.Купалової, О. А. Лаговської, І. Д. Лазаришиної, С. З. Мошенського, О. В. Олійник, І. М. Парасій-Вергуненко, О.Г.Янкового, С.І.Шкарабана та ін. Ïх внесок у розвиток факторного аналізу $є$ значним, проте відсутність єдиного комплексного підходу перешкоджає ефективному проведенню факторного аналізу фінансових результатів основної та операційної діяльності будівельних підприємств. Дослідження напрацювань вітчизняних науковців свідчить про необхідність уточнення базових положень такого аналізу. Зважаючи на вищевикладене, актуальним нині $€$ дослідження методики факторного аналізу фінансових результатів основної та операційної 
діяльності будівельних підприємств.

Постановка завдання. Мета дослідження полягає у проведенні факторного аналізу фінансових результатів основної, операційної діяльності будівельних підприємств та чистого прибутку кількома прийомами елімінування, а саме: методом ланцюгових підстановок та прийомом відносних різниць. Досягнення поставленої мети передбачає розв'язання таких завдань: дослідити сутність факторного аналізу, провести факторний аналіз валового прибутку, прибутку операційної діяльності, чистого прибутку методом ланцюгових підстановок та прийомом відносних різниць, ідентифікувати результати факторного аналізу.

Викладення основного матеріалу. На величину фінансових результатів впливає низка чинників. Результати проведеного аналізу факторів впливу на величину прибутку підприємств у працях науковців: [4, С. 48; 5; 6, С. 99; 7, С. 300; 8, С. 179; 9, С. 76] дають підстави ідентифікувати чинники впливу на прибуток будівельних підприємств (рис. 1).

Нами запропоновано їх виокремити у такі групи: зовнішні (не залежать від діяльності підприємства) й внутрішні фактори (пріоритетні при здійсненні впливу на величину прибутку), які в свою чергу доцільно класифікувати на виробничі і невиробничі, адже будівельне підприємство, крім ведення основної діяльності, може займатися іншими видами діяльності, де беруть участь невиробничі основні засоби. Екстенсивні фактори чинять влив на розмір прибутку шляхом кількісних змін, інтенсивні - через якісні зміни. Одним із важливих внутрішніх чинників величини прибутку $\epsilon$ облікова політика підприємства. Як констатує М.О.Бляхарчук, «...продумана облікова політика допоможе достовірно визначити прибуток, що дозволить заощадити на податкових платежах» [10, С. 27].

В управлінні господарюючими суб'єктами особлива роль відводиться факторному аналізу, що надає можливість формувати та змінювати параметри об'єктів управління шляхом підбору чинників, які їх обумовлюють. В основу факторного аналізу покладено побудову факторної моделі, в якій фактори перебувають у причиннонаслідкових зв'язках із результативним показником.

Загалом факторний аналіз - це комплексне вивчення оцінки впливу окремих факторів на величину результативних показників. Факторний аналіз здійснюється із застосуванням таких прийомів: ланцюгових підстановок, відносних різниць та абсолютних різниць. 


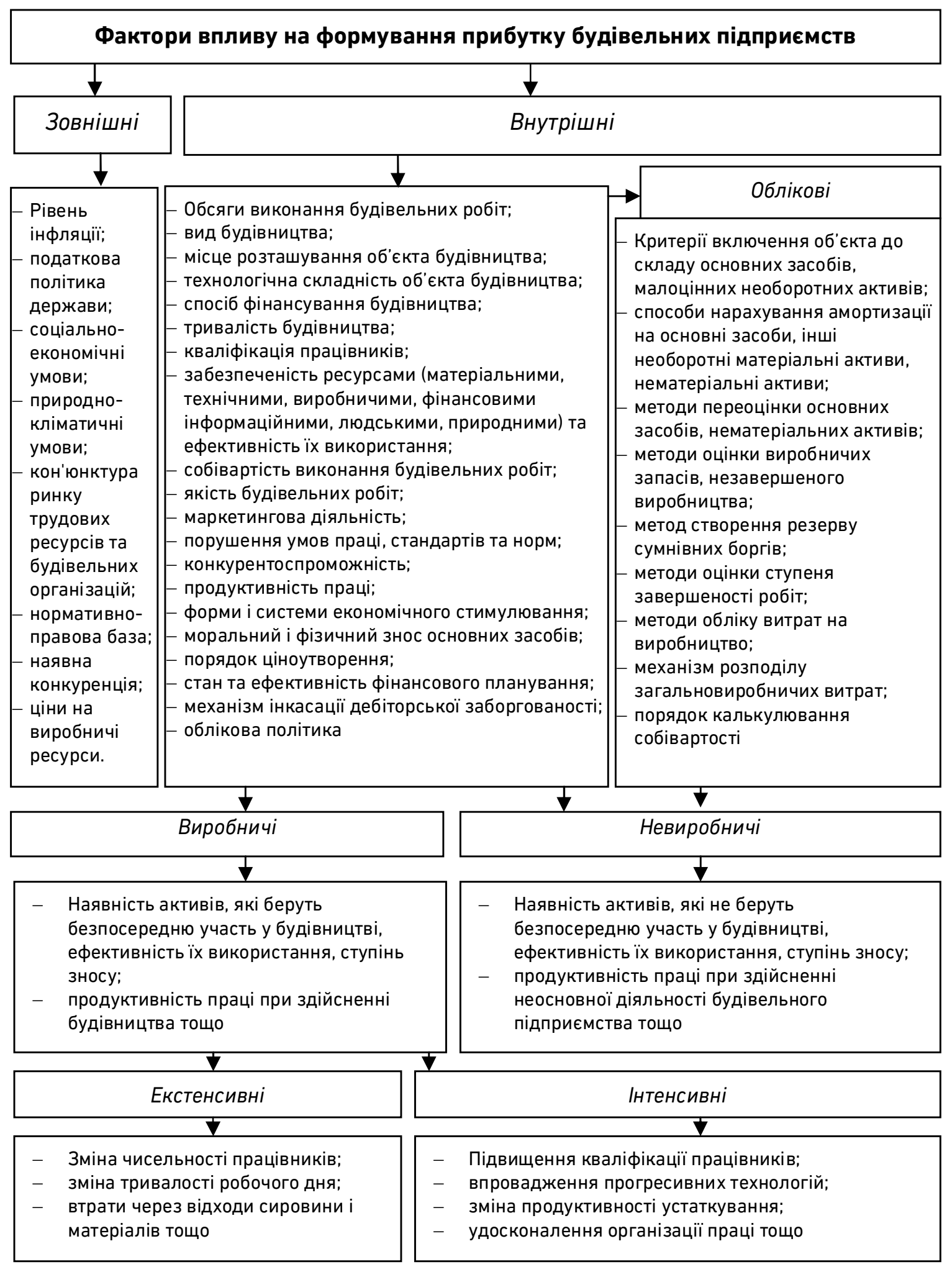

Рис. 1. Фактори впливу на формування прибутку будівельних підприємств* *Розроблено автором. 
Ступінь впливу кожного з факторів на результативний показник може бути визначений із застосуванням способу ланцюгових підстановок, оскільки результативний показник розраховується за допомогою комбінованої (змішаної) детермінованої факторної моделі [2, С. 110]. Цей спосіб дозволяє визначити вплив окремих факторів на зміну величини результативного показника шляхом поступової заміни базисної величини кожного факторного показника в обсязі результативного на фактичну величину у звітному періоді [3, С. 159]. Вихідні дані для факторного аналізу фінансових результатів основної діяльності методом ланцюгових підстановок ТзОВ «Реноме-Євробуд» за 2014-2018 рр. наведено у табл. 1.

Таблиця 1

Вихідні дані для факторного аналізу фінансових результатів основної діяльності методом ланцюгових підстановок

ТзОВ «Реноме-Євробуд» за 2014-2018 рр.

\begin{tabular}{|c|c|c|c|c|c|c|c|c|c|}
\hline \multirow[b]{2}{*}{ Показники } & \multirow[b]{2}{*}{2014} & \multirow[b]{2}{*}{2015} & \multirow[b]{2}{*}{2016} & \multirow[b]{2}{*}{2017} & \multirow[b]{2}{*}{2018} & \multicolumn{4}{|c|}{ Абсолютне відхилення (+;-) } \\
\hline & & & & & & $\begin{array}{c}2015 / \\
2014\end{array}$ & $\begin{array}{c}2016 / \\
2015\end{array}$ & $\begin{array}{c}2017 / \\
2016\end{array}$ & $\begin{array}{c}2018 / \\
2017\end{array}$ \\
\hline $\begin{array}{l}\text { 1. Чистий дохід } \\
\text { від реалізації } \\
\text { продукції } \\
\text { (товарів, робіт, } \\
\text { послуг), тис. грн } \\
\left(\mathbf{x}_{1}\right)\end{array}$ & 29965 & 36861 & $126814 \mid$ & 213895 & 221722 & 6896 & 89953 & 87081 & 7827 \\
\hline $\begin{array}{l}\text { 2. Собівартість } \\
\text { реалізованої } \\
\text { продукції } \\
\text { (товарів, робіт, } \\
\text { послуг), тис. грн }\end{array}$ & 25482 & 33732 & 115122 & 179727 & 190366 & 8250 & 81390 & 64605 & 10639 \\
\hline $\begin{array}{l}\text { 3. Частка } \\
\text { собівартості в } \\
\text { чистому доході } \\
\text { від реалізації } \\
\text { продукції } \\
\text { (товарів, робіт, } \\
\text { послуг), \% (х2) }\end{array}$ & 85,04 & 91,51 & 90,78 & 84,03 & 85,86 & 6,47 & $-0,73$ & $-6,75$ & 1,83 \\
\hline $\begin{array}{l}\text { 4. Валовий } \\
\text { прибуток, } \\
\text { тис. грн (у) }\end{array}$ & 4483 & 3129 & 11692 & 34168 & 31356 & -1354 & 8563 & 22476 & -2812 \\
\hline
\end{tabular}

Для проведення факторного аналізу фінансових результатів основної діяльності будівельного підприємства ТзОВ «РеномеЄвробуд» методом ланцюгових підстановок пропонуємо використати таку факторну модель (1): 


$$
y=x_{1}-\frac{x_{1} \times x_{2}}{100},
$$

де $x_{1}-$ чистий дохід від реалізації продукції (товарів, робіт, послуг), тис. грн;

$x_{2}$ - частка собівартості в чистому доході від реалізації продукції (товарів, робіт, послуг), \%;

у- валовий прибуток, тис. грн.

Виконуючи послідовну заміну факторів, одержимо такі результати (табл. 2).

Таблиця 2

Результати факторного аналізу фінансових результатів основної діяльності методом ланцюгових підстановок ТзОВ «Реноме-Євробуд» за 2014-2018 рр.

\begin{tabular}{|l|c|c|c|c|}
\hline \multicolumn{1}{|c|}{ Показники } & $2015 / 2014$ & $2016 / 2015$ & $2017 / 2016$ & $2018 / 2017$ \\
\hline $\begin{array}{l}\text { 1. Вплив чистого доходу } \\
\text { від реалізації продукції } \\
\text { (товарів, робіт, послуг), } \\
\text { тис. грн }\end{array}$ & 1031,406 & 7637,509 & 8029,119 & 1250,294 \\
\hline $\begin{array}{l}\text { 2. Вплив частки } \\
\text { собівартості в чистому } \\
\text { доході від реалізації } \\
\text { продукції (товарів, робіт, } \\
\text { послуг), тис. грн }\end{array}$ & $-2384,91$ & 925,7422 & 14437,91 & $-4062,3$ \\
\hline $\begin{array}{l}\text { З. Загальний вплив } \\
\text { факторів на величину } \\
\text { валового прибутку, } \\
\text { тис. грн }\end{array}$ & $\mathbf{- 1 3 5 3 , 5}$ & $\mathbf{8 5 6 3 , 2 5}$ & $\mathbf{2 2 4 6 7}$ & $\mathbf{- 2 8 1 2 , 0 1}$ \\
\hline
\end{tabular}

Відтак, заявлені фактори по-різному впливають на величину фінансового результату основної діяльності - валового прибутку. Найбільш позитивний плив фактори чинили у 2017 р. порівняно 3 2016 р., оскільки саме у 2017 р. діяльність досліджуваного господарюючого суб'єкта характеризується найвищим значенням валового прибутку (прибутку від ведення основної діяльності). Так, динаміка чистого доходу від реалізації продукції (товарів, робіт, послуг) (його зростання на 87081 тис. грн) зумовила збільшення валового прибутку на 7637,509 тис. грн, а зміна частки собівартості в чистому доході від реалізації продукції (товарів, робіт, послуг) (iï зменшення на 6,75\%) спричинила збільшення результативного показника - валового прибутку на 925,7422 тис. грн. Сукупний вплив факторів $є$ позитивним і становить 22467 тис. грн, тобто спостерігається зростання валового прибутку на 22476 тис. грн. Натомість у 2018 р. ТзОВ «Реноме-Євробуд» одержало на 
2812 тис. грн менше валового прибутку порівняно 3 попереднім (2017р.), на що безумовно вплинули заявлені фактори: динаміка чистого доходу від реалізації продукції (товарів, робіт, послуг) (його зростання на 7827 тис. грн) викликала збільшення валового прибутку на 1250,294 тис. грн, а збільшення частки собівартості в чистому доході (на 1,83\%) зумовило зменшення валового прибутку на 4062,3 тис. грн, що оцінюється негативно.

Вихідні дані для факторного аналізу фінансових результатів операційної діяльності методом ланцюгових підстановок ТзОВ «Реноме-Євробуд» за 2014-2018 рр. наведено у табл. 3.

Таблиця 3

Вихідні дані для факторного аналізу фінансових результатів операційної діяльності методом ланцюгових підстановок ТзОВ «Реноме-Євробуд» за 2014-2018 рр.

\begin{tabular}{|c|c|c|c|c|c|c|c|c|c|}
\hline \multirow[b]{2}{*}{ Показники } & \multirow[b]{2}{*}{2014} & \multirow[b]{2}{*}{2015} & \multirow[b]{2}{*}{2016} & \multirow[b]{2}{*}{2017} & \multirow[b]{2}{*}{2018} & \multicolumn{4}{|c|}{ Абсолютне відхилення (+;-) } \\
\hline & & & & & & \begin{tabular}{|c|}
2015 \\
2014
\end{tabular} & $\begin{array}{c}2016 / \\
2015\end{array}$ & $\begin{array}{c}2017 / \\
2016\end{array}$ & $\mid \begin{array}{c}2018 \\
2017\end{array}$ \\
\hline 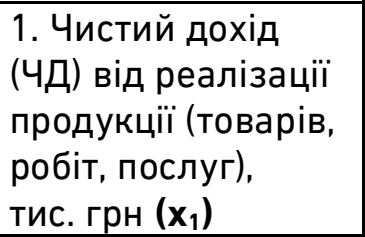 & 29965 & 36861 & 126814 & 213895 & 221722 & 6896 & 89953 & 87081 & 7827 \\
\hline $\begin{array}{l}\text { 2. Частка } \\
\text { собівартості в ЧД, } \\
\%\left(\mathbf{x}_{2}\right)\end{array}$ & 85,0 & 91,5 & 90,8 & 84,0 & 85,9 & 6,5 & $-0,7$ & $-6,8$ & 1,8 \\
\hline $\begin{array}{l}\text { 3. Частка } \\
\text { адміністративних } \\
\text { витрат в ЧД, \% }\left(\mathbf{x}_{3}\right)\end{array}$ & 4,1 & 4,7 & 1,4 & 1,5 & 1,3 & 0,6 & $-3,4$ & 0,1 & $-0,2$ \\
\hline $\begin{array}{l}\text { 4. Частка витрат } \\
\text { на збут в ЧД, \% } \\
\left(\mathbf{x}_{4}\right) \\
\end{array}$ & 7,6 & 1,1 & 1,3 & 0,9 & 0,8 & $-6,5$ & 0,2 & $-0,3$ & $-0,1$ \\
\hline $\begin{array}{l}\text { 5. Частка інших } \\
\text { операційних } \\
\left.\text { витрат в Чд, \% ( } \mathbf{x}_{5}\right)\end{array}$ & 5,2 & 1,0 & 0,8 & 8,7 & 9,2 & $-4,2$ & $-0,2$ & 7,9 & 0,5 \\
\hline $\begin{array}{l}\text { 6. Частка інших } \\
\text { операційних } \\
\text { доходів в ЧД, \% } \\
\left(\mathbf{x}_{6}\right) \\
\end{array}$ & 8,0 & 12,0 & 1,4 & 0,9 & 2,4 & 4,0 & $-10,6$ & $-0,6$ & 1,5 \\
\hline $\begin{array}{l}\text { 7. Прибуток від } \\
\text { операційної } \\
\text { діяльності, (у) }\end{array}$ & 1808 & 5036 & 9121 & 12235 & 11642 & 3228 & 4085 & 3114 & -593 \\
\hline $\begin{array}{l}\text { 8. Частка прибутку } \\
\text { від операційної } \\
\text { діяльності в ЧД, \% } \\
\left(\mathbf{x}_{\mathbf{7}}\right)\end{array}$ & 6,0 & 13,7 & 7,2 & 5,7 & 5,3 & 7,6 & $-6,5$ & $-1,5$ & $-0,5$ \\
\hline 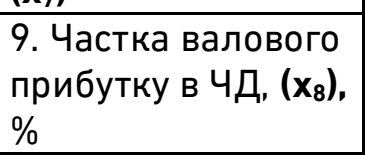 & 15,0 & 8,5 & 9,2 & 16,0 & 14,1 & $-6,5$ & 0,7 & 6,8 & $-1,8$ \\
\hline
\end{tabular}


Для проведення факторного аналізу фінансових результатів операційної діяльності будівельного підприємства ТзОВ «РеномеЄвробуд» методом ланцюгових підстановок пропонуємо використати таку факторну модель (2):

$$
y=x_{1}-\frac{x_{1} \times x_{2}}{100}-\frac{x_{1} \times x_{3}}{100}-\frac{x_{1} \times x_{4}}{100}-\frac{x_{1} \times x_{5}}{100}+\frac{x_{1} \times x_{6}}{100},
$$

де у - прибуток від операційної діяльності, тис. грн;

$x_{1}$ - чистий дохід від реалізації продукції (товарів, робіт, послуг), тис. грн;

$x_{2}$ - частка собівартості в чистому доході від реалізації продукції (товарів, робіт, послуг), \%;

$x_{3}$ - частка адміністративних витрат в чистому доході від реалізації продукції (товарів, робіт, послуг), \%;

$x_{4}$ - частка витрат на збут в чистому доході від реалізації продукції (товарів, робіт, послуг), \%;

$x_{5}$ - частка інших операційних витрат в чистому доході від реалізації продукції (товарів, робіт, послуг), \%;

$x_{6}$ - частка інших операційних доходів в чистому доході від реалізації продукції (товарів, робіт, послуг), \%.

Виконуючи послідовну заміну факторів, одержимо такі результати (табл. 4).

Отже, найбільш позитивний вплив на динаміку результативного показника обрані фактори чинили у 2016 р. порівняно з 2015 р. Сукупний вплив чинників становив 4084,24 тис. грн. Збільшення чистого доходу від реалізації продукції (товарів, робіт, послуг) ТзОВ «Реноме-Євробуд» на 89953 тис. грн зумовило зростання прибутку від операційної діяльності на 12288,91 тис. грн. Зменшення частки собівартості в чистому доході на 0,7\% викликало підвищення величини прибутку на 927,21 тис. грн.

Скорочення частки адміністративних витрат на $3,4 \%$ збільшення розміру прибутку на 4255,88 тис. грн; зростання частки витрат на збут на 0,2\% - зменшення прибутку на 194,03 тис. грн; скорочення частки інших операційних витрат в чистому доході від реалізації продукції (товарів, робіт, послуг) на 0,2\% - зростання прибутку на 232,07 тис. грн; скорочення частки інших операційних доходів в чистому доході від реалізації продукції (товарів, робіт, послуг) на 10,6\% - зменшення прибутку на 13425,8 тис. грн. Таким чином, загальний вплив факторів оцінюється як позитивний $\mathrm{i}$ становить 4084,24 тис. грн. 
Таблиця 4

Результати факторного аналізу фінансових результатів операційної діяльності методом ланцюгових підстановок ТзОВ «Реноме-Євробуд» за 2014-2018 pp.

\begin{tabular}{|l|c|c|c|c|}
\hline \multicolumn{1}{|c|}{ Показники } & $2015 / 2014$ & $2016 / 2015$ & $2017 / 2016$ & $2018 / 2017$ \\
\hline $\begin{array}{l}\text { 1. Вплив чистого доходу від } \\
\text { реалізації продукції (товарів, } \\
\text { робіт, послуг), тис. грн }\end{array}$ & 415,64 & 12288,91 & 6263,47 & 447,71 \\
\hline $\begin{array}{l}\text { 2. Вплив частки собівартості } \\
\text { в чистому доході, тис. грн }\end{array}$ & $-2385,70$ & 927,21 & 14447,30 & $-4062,30$ \\
\hline $\begin{array}{l}\text { 3. Вплив частки } \\
\text { адміністративних витрат в } \\
\text { чистому доході, тис. грн }\end{array}$ & $-226,78$ & 4255,88 & $-315,62$ & 460,62 \\
\hline $\begin{array}{l}\text { 4. Вплив частки витрат на } \\
\text { збут в чистому доході, } \\
\text { тис. грн }\end{array}$ & 2382,18 & $-194,03$ & 739,49 & 285,79 \\
\hline $\begin{array}{l}\text { 5. Вплив частки інших } \\
\text { операційних витрат в } \\
\text { чистому доході, тис. грн }\end{array}$ & 1560,39 & 232,07 & $-16841,78$ & $-1115,33$ \\
\hline $\begin{array}{l}\text { 6. Вплив частки інших } \\
\text { операційних доходів в } \\
\text { чистому доході, тис. грн }\end{array}$ & 1481,83 & $-13425,80$ & $-1179,21$ & 3390,50 \\
\hline $\begin{array}{l}\text { 7. Загальний вплив факторів } \\
\text { на величину прибутку від } \\
\text { операційної діяльності, } \\
\text { тис. грн }\end{array}$ & 3227,56 & 4084,24 & 3113,66 & $-593,00$ \\
\hline
\end{tabular}

Проте в 2018 р. спостерігається скорочення розміру прибутку від операційної діяльності на 593 тис. грн, що менш позитивно характеризує діяльність господарюючого суб'єкта. При цьому найбільш негативний вплив справило зростання частки собівартості в чистому доході: його збільшення на 1,8\% спричинило зменшення прибутку на 4062,3 тис. грн. Однак, потрібно відмітити, що значення прибутку від операційної діяльності досліджуваного будівельного підприємства $є$ значними у всі аналізовані роки.

Використовуючи вихідні дані для факторного аналізу фінансових результатів операційної діяльності методом відносних різниць ТзОВ «Реноме-Євробуд» за 2014-2018 рр., наведені у табл. 3, виконаємо відповідні розрахунки щодо впливу факторів на величину прибутку операційної діяльності прийомом відносних різниць. Для цього пропонуємо використовуючи таку факторну модель (3):

$$
y=x_{1} * \frac{\left(x_{8}-x_{3}-x_{4}-x_{5}+x_{6}\right)}{100},
$$

де $y$ - прибуток від операційної діяльності; 
$x_{1}$ - чистий дохід від реалізації продукції (товарів, робіт, послуг);

$x_{3}$ - частка адміністративних витрат в чистому доході від реалізації продукції (товарів, робіт, послуг);

$x_{4}$ - частка витрат на збут в чистому доході від реалізації продукції (товарів, робіт, послуг);

$x_{5}$ - частка інших операційних витрат в чистому доході від реалізації продукції (товарів, робіт, послуг);

$x_{6}$ - частка інших операційних доходів в чистому доході від реалізації продукції (товарів, робіт, послуг);

$x_{8}$ - частка валового прибутку в чистому доході від реалізації продукції (товарів, робіт, послуг).

Для обчислення впливу факторів методом відносних різниць використаємо низку формул (позначення заявлені вище по тексту):

Вплив чистого доходу від реалізації продукції (товарів, робіт, послуг) на величину прибутку від операційної діяльності (4):

$$
\Delta y_{x 1}=x_{7}{ }^{0} \times \frac{\left(x_{1}{ }^{1}-x_{1}{ }^{0}\right)}{100}
$$

Вплив валового прибутку від реалізації на величину прибутку від операційної діяльності (5):

$$
\Delta y_{x 1}=x_{1}{ }^{1} \times \frac{\left(x_{8}{ }^{1}-x_{8}{ }^{0}\right)}{100}
$$

Вплив частки адміністративних витрат в чистому доході від реалізації продукції (товарів, робіт, послуг) на величину прибутку від операційної діяльності (6):

$$
\Delta y_{x 1}=x_{1}{ }^{1} \times \frac{\left(x_{3}{ }^{1}-x_{3}{ }^{0}\right)}{100}
$$

Вплив частки витрат на збут в чистому доході від реалізації продукції (товарів, робіт, послуг) на величину прибутку від операційної діяльності (7):

$$
\Delta y_{x 1}=x_{1}{ }^{1} \times \frac{\left(x_{4}{ }^{1}-x_{4}{ }^{0}\right)}{100}
$$

Вплив частки інших операційних витрат в чистому доході від реалізації продукції (товарів, робіт, послуг) на величину прибутку від операційної діяльності (8): 


$$
\Delta y_{x 1}=x_{1}{ }^{1} \times \frac{\left(x_{5}{ }^{1}-x_{5}{ }^{0}\right)}{100} .
$$

Вплив частки інших операційних доходів в чистому доході від реалізації продукції (товарів, робіт, послуг) на величину прибутку від операційної діяльності (9):

$$
\Delta y_{x 1}=x_{1}^{1} \times \frac{\left(x_{6}{ }^{1}-x_{6}{ }^{0}\right)}{100} .
$$

Виконуючи відповідні розрахунки, одержимо такі результати (табл. 5).

Таблиця 5

Результати факторного аналізу фінансових результатів операційної діяльності методом відносних різниць ТзОВ «Реноме-Євробуд»

\begin{tabular}{|l|c|c|c|c|}
\multicolumn{1}{|c}{ По 2014-2018 рр. } \\
\hline $\begin{array}{l}\text { П. Вплив чистого доходу від } \\
\text { реалізації продукції (товарів, } \\
\text { робіт, послуг) (ЧД), тис. грн }\end{array}$ & $2015 / 2014$ & $2016 / 2015$ & $2017 / 2016$ & $2018 / 2017$ \\
\hline $\begin{array}{l}\text { 2. Вплив валового прибутку від } \\
\text { реалізації, тис. грн }\end{array}$ & $-2385,7$ & 927,2 & 14447,3 & $-4062,3$ \\
\hline $\begin{array}{l}\text { 3. Вплив частки } \\
\text { адміністративних витрат у ЧД, } \\
\text { тис. грн }\end{array}$ & $-226,8$ & 4255,8 & $-315,6$ & 460,6 \\
\hline $\begin{array}{l}\text { 4. Вплив частки витрат на збут } \\
\text { в ЧД, тис. грн }\end{array}$ & 2382,2 & $-194,9$ & 740,1 & 285,8 \\
\hline $\begin{array}{l}\text { 5. Вплив частки інших } \\
\text { операційних витрат в Чд, } \\
\text { тис. грн }\end{array}$ & 1560,4 & 232,2 & $-16841,8$ & $-1115,3$ \\
\hline $\begin{array}{l}\text { 6. Вплив частки інших } \\
\text { операційних доходів в чД, } \\
\text { тис. грн }\end{array}$ & 1481,8 & $-13424,8$ & $-1179,2$ & 3390,5 \\
\hline $\begin{array}{l}\text { 7. Загальний вплив факторів } \\
\text { на величину прибутку від } \\
\text { операційної діяльності, тис. грн }\end{array}$ & 3227,6 & 4084,2 & 3113,7 & $-593,0$ \\
\hline
\end{tabular}

Відтак, можна констатувати, що результати факторного аналізу фінансових результатів операційної діяльності прийомом ланцюгових підстановок (табл. 4) і результати факторного аналізу фінансових результатів операційної діяльності прийомом відносних різниць (табл. 5) по спільних показниках є однаковими. Відмінність складають значення показників, що відображають вплив валового прибутку від реалізації (табл.5) та вплив частки собівартості в чистому доході від реалізації продукції (товарів, робіт, послуг) (табл. 4) на значення прибутку від операційної діяльності.

Наступним етапом проведемо факторний аналіз чистого 178 
прибутку іншого будівельного підприємства - ПП «Рівнеспецбуд», використовуючи дані ф. № 2-м «Звіт про фінансові результати» за 2015-2018 рр. Спрощений звіт за формою № 2-м містить дещо інший перелік показників, отже, унеможливлюється застосування методик, апробованих вище на прикладі ТзОВ «Реноме-Євробуд».

Вихідні дані для факторного аналізу чистого прибутку методом ланцюгових підстановок ПП «Рівнеспецбуд» за 2015-2018 рр. наведено у табл. 6.

Таблиця 6

Вихідні дані для факторного аналізу чистого прибутку методом ланцюгових підстановок ПП «Рівнеспецбуд» за 2015-2018 рр.

\begin{tabular}{|c|c|c|c|c|c|c|c|}
\hline \multirow{2}{*}{ Показники } & \multirow{2}{*}{2015} & \multirow{2}{*}{2016} & \multirow{2}{*}{2017} & \multirow{2}{*}{2018} & \multicolumn{3}{|c|}{$\begin{array}{c}\text { Абсолютне відхилення } \\
(+;-)\end{array}$} \\
\hline & & & & & $\begin{array}{l}2016 / \\
2015\end{array}$ & $\begin{array}{l}2017 / \\
2016\end{array}$ & $\begin{array}{l}2018 / \\
2017\end{array}$ \\
\hline $\begin{array}{l}\text { 1. Чистий дохід } \\
\text { (ЧД) від реалізації } \\
\text { продукції (товарів, } \\
\text { робіт, послуг), } \\
\text { тис. грн }\left(\mathbf{x}_{1}\right) \\
\end{array}$ & 9645,6 & 14912,4 & 16501,9 & 18964,9 & 5266,8 & 1589,5 & 2463,0 \\
\hline $\begin{array}{l}\text { 2. Частка інших } \\
\text { операційних } \\
\left.\text { доходів в ЧД, \% ( } \mathbf{x}_{2}\right)\end{array}$ & 0,0 & 0,0 & 0,0 & 0,0 & 0,0 & 0,0 & 0,0 \\
\hline $\begin{array}{l}\text { 3. Частка собі вар- } \\
\left.\text { тості в ЧД, \% ( } \mathbf{x}_{3}\right)\end{array}$ & 85,8 & 91,8 & 90,6 & 94,5 & 6,0 & $-1,2$ & 4,0 \\
\hline $\begin{array}{l}\text { 4. Частка інших } \\
\text { операційних } \\
\left.\text { витрат в ЧД, \% ( } \mathbf{x}_{\mathbf{4}}\right)\end{array}$ & 12,5 & 6,3 & 8,3 & 4,3 & $-6,2$ & 2,0 & $-4,0$ \\
\hline $\begin{array}{l}\text { 5. Частка податку } \\
\text { на прибуток в ЧД, } \\
\%\left(\mathbf{x}_{5}\right)\end{array}$ & 0,3 & 0,3 & 0,2 & 0,2 & 0,0 & $-0,1$ & 0,0 \\
\hline $\begin{array}{l}\text { 6. Чистий } \\
\text { прибуток, (y) }\end{array}$ & 137,6 & 228,3 & 152,0 & 187,7 & 90,7 & $-76,3$ & 35,7 \\
\hline
\end{tabular}

Розрахунки щодо впливу факторів на величину чистого прибутку прийомом ланцюгових підстановок проведемо, використовуючи таку факторну модель (10):

$$
y=x_{1}+\frac{x_{1} \times x_{2}}{100}-\frac{x_{1} \times x_{3}}{100}-\frac{x_{1} \times x_{4}}{100}-\frac{x_{1} \times x_{5}}{100},
$$

де $y$ - фінансовий результат після оподаткування (чистий прибуток);

$x_{1}$ - чистий дохід від реалізації продукції (товарів, робіт, послуг);

$x_{2}$ - частка інших операційних доходів в чистому доході від реалізації продукції (товарів, робіт, послуг); 
$x_{3}$ - частка собівартості в чистому доході від реалізації продукції (товарів, робіт, послуг);

$x_{4}$ - частка інших операційних витрат в чистому доході від реалізації продукції (товарів, робіт, послуг);

$x_{5}$ - частка податку на прибуток в чистому доході від реалізації продукції (товарів, робіт, послуг).

Виконавши відповідні розрахунки щодо послідовної заміни факторів, одержимо такі результати (табл. 7).

Таблиця 7

Результати факторного аналізу чистого прибутку методом ланцюгових підстановок ПП «Рівнеспецбуд» за 2015-2018 рр.

\begin{tabular}{|l|c|c|c|}
\hline \multicolumn{1}{|c|}{ Показники } & $2016 / 2015$ & $2017 / 2016$ & $2018 / 2017$ \\
\hline $\begin{array}{l}\text { 1. Вплив чистого доходу від реалізації } \\
\text { продукції (товарів, робіт, послуг), тис. грн }\end{array}$ & 75,057 & 24,334 & 22,687 \\
\hline $\begin{array}{l}\text { 2. Вплив частки інших операційних } \\
\text { доходів в чистому доході від реалізації } \\
\text { продукції (товарів, робіт, послуг), тис. грн }\end{array}$ & $-3,679$ & 0,660 & $-0,046$ \\
\hline $\begin{array}{l}\text { 3. Вплив частки собівартості в чистому } \\
\text { доході від реалізації продукції (товарів, } \\
\text { робіт, послуг), тис. грн }\end{array}$ & $-894,891$ & 200,824 & $-751,952$ \\
\hline $\begin{array}{l}\text { 4. Вплив частки інших операційних } \\
\text { витрат в чистому доході від реалізації } \\
\text { продукції (товарів, робіт, послуг), тис. грн }\end{array}$ & 917,630 & $-324,299$ & 767,999 \\
\hline $\begin{array}{l}\text { 5. Вплив частки податку на прибуток в } \\
\text { чистому доході від реалізації продукції } \\
\text { (товарів, робіт, послуг), тис. грн }\end{array}$ & $-3,410$ & 22,140 & $-2,930$ \\
\hline $\begin{array}{l}\text { б. Загальний вплив факторів на величину } \\
\text { фінансового результату після } \\
\text { оподаткування, тис. грн }\end{array}$ & 90,708 & $-76,340$ & 35,759 \\
\hline
\end{tabular}

Таким чином, зростання чистого прибутку ПП «Рівнеспецбуд» спостерігається у 2016 р. та 2018 р. відповідно на 90,7 тис. грн та 35,7 тис. грн. Найбільш позитивний вплив при цьому справило зменшення частки інших операційних витрат у структурі чистого доходу від реалізації продукції (товарів, робіт, послуг) (на 6,2 \% та 4,0\% відповідно). Негативний вплив спричинило збільшення частки собівартості у структурі чистого доходу від реалізації продукції (товарів, робіт, послуг) (на 6,0\% та 4,0\% відповідно).

Оцінюючи вплив факторів у 2017 р. порівняно 32016 р., відмітимо суттєве зменшення чистого прибутку, що характеризує не досить ефективні результати функціонування досліджуваного господарюючого суб'єкта. Зростання розміру чистого доходу на 1589,5 тис. грн викликало збільшення чистого прибутку на 24,334 тис. грн. Незначна зміна інших операційних доходів зумовила 
збільшення чистого прибутку на 0,66 тис. грн. Зменшення частки собівартості у чистому доході (на 1,2 тис. грн) спричинило зростання чистого прибутку - на 200,824 тис. грн, що оцінюється позитивно. Зростання частки інших операційних витрат у структурі доходу, що відбулося у 2017 р., а саме - на 2,0 тис. грн, спровокувало зменшення величини фінансового результату після оподаткування на 324,299 тис. грн., що є досить негативним. Вплив динаміки частки податку на прибуток підприємства у структурі чистого доходу становить 22,14 тис. грн у бік збільшення чистого прибутку. Сукупний вплив факторів оцінюється як негативний. Проте вже наступного 2018 р. ситуація дещо змінилася, і значення чистого прибутку збільшилося на 35,7 тис. грн.

Характеризуючи вплив факторів у 2018 р. порівняно 32017 р., відмітимо наступне. Зростання розміру чистого доходу на 2463 тис.грн викликало збільшення чистого прибутку на 22,687 тис. грн. Незначна зміна інших операційних доходів зумовила зменшення чистого прибутку на 0,046 тис. грн. Зростання частки собівартості у чистому доході (на 4,0 тис. грн) спричинило значне скорочення розміру чистого прибутку - на 751,952 тис. грн, що оцінюється негативно. Важливим $€$ зменшення частки інших операційних витрат у структурі доходу, що відбулося у 2018 р., а саме - на 4,0 тис. грн, адже воно спровокувало підвищення величини фінансового результату після оподаткування на 767,999 тис. грн. Вплив динаміки частки податку на прибуток підприємства у структурі чистого доходу є несуттєвим, і становить 2,93 тис. грн у бік зменшення чистого прибутку. Сукупний вплив факторів оцінюється як позитивний.

Підсумовуючи вищевикладене, зазначимо, що важливу роль у формуванні прибутку відіграє собівартість і їі частка у структурі чистого доходу від реалізації продукції (товарів, робіт, послуг). Собівартість як найважливіший показник ефективності функціонування будівельного підприємства, що направлений на відображення у вартісному вираженні витрат на придбання матеріалів та інших засобів виробництва, оплату праці робітників, які беруть участь у виконанні БМР, витрат з управління, організації та обслуговування будівельних майданчиків, безперечно, чинить істотний вплив на рівень рентабельності господарюючого суб'єкта.

Характеристика собівартості як економічної категорії щодо будівництва має певні особливості. Витрати на реалізацію продукції у будівництві значно менші, аніж у промисловості, адже підрядний спосіб виконання робіт передбачає здійснення БМР відразу на місці ї використання замовником. Економічний зміст собівартості у будівництві відрізняється від собівартості у промисловості, яка 
формується на основі індивідуальних витрат на виробництво виробу. Трактування собівартості подано у табл. 8.

Дані табл. 8 свідчать про те, що найбільш поширеним серед науковців $€$ універсальне визначення собівартості БМР як фактичних затрат будівельного підприємства, які пов'язані із виконанням БМР та випуском продукції і послуг. Підсумовуючи зазначене, пропонуємо розглядати собівартість будівельних робіт як узагальнений показник ефективності господарювання будівельних підприємств, що передбачає включення до свого складу вартості необхідних матеріально-технічних та трудових ресурсів, витрат на утримання апаратів управління відокремлених виробничих підрозділів, витрат, понесених при здачі замовнику об'єктів будівництва тощо, а також вартості БМР, виконаних субпідрядними організаціями.

Слід наголосити на тому, що в обліку виконання будівельних робіт використовується термін «витрати за будівельним контрактом», які відповідно до п. 2 П(С)БО 18 «Будівельні контракти» являють собою собівартість робіт за будівельним контрактом. Згідно 3 п. 2. першого розділу Методичних рекомендацій з формування собівартості будівельно-монтажних робіт № 573 від 31.12 .2010 р. собівартість БМР - це виробничі витрати будівельної організації, пов'язані з виконанням БМР [19]. Мінімізація собівартості, яка передбачає економію трудових, матеріальних та фінансових ресурсів, збільшення продуктивності праці, скорочення тривалості будівництва об'єктів, покращення якості робіт, і $\epsilon$ основним завданням управлінського персоналу, можлива лише за умови належного ведення бухгалтерського обліку, спрямованого на забезпечення правдивості та неупередженості даних щодо витрат, які здійснені під час виконання будівельних контрактів.

Найважливішими чинниками максимізації прибутку будівельних підприємств $€$ саме внутрішні фактори: збільшення обсягу виконання будівельних робіт за одночасної мінімізації їх собівартості; підвищення якості будівельної продукції; зростання продуктивності праці та ін. 
Визначення собівартості будівельно-монтажних робіт

\begin{tabular}{|c|c|c|c|c|c|c|c|c|c|}
\hline $\begin{array}{l}\text { № } \\
3 / \Pi\end{array}$ & Визначення собівартості & 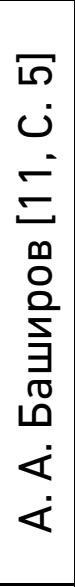 & 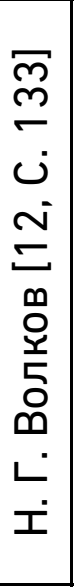 & 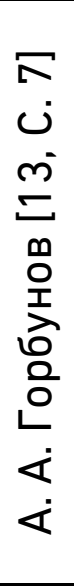 & 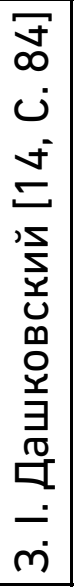 & 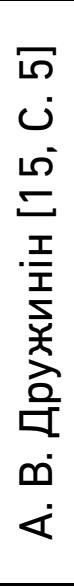 & 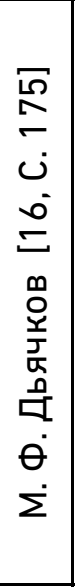 & 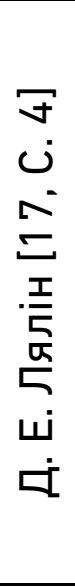 & 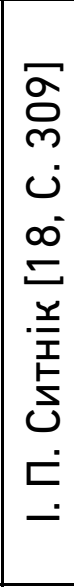 \\
\hline 1. & $\begin{array}{l}\text { Затрати підрядних будівельно- } \\
\text { монтажних організацій на } \\
\text { виробництво, які являють собою } \\
\text { інвентарну вартість основних фондів, } \\
\text { що вводяться у дію }\end{array}$ & + & & & & & & & \\
\hline 2. & $\begin{array}{l}\text { Фактичні затрати будівельної } \\
\text { організації, пов'язані із виконанням } \\
\text { будівельно-монтажних робіт і } \\
\text { випуском продукції та послуг }\end{array}$ & & + & + & & & & & + \\
\hline 3. & $\begin{array}{l}\text { Затрати на БМР, що виконуються } \\
\text { власними силами, пов'язані із } \\
\text { використанням у процесі } \\
\text { будівельного виробництва машин, } \\
\text { механізмів та інших основних фондів, } \\
\text { матеріальних, трудових та інших } \\
\text { виробничих ресурсів }\end{array}$ & & & & & + & + & & \\
\hline 4. & $\begin{array}{l}\text { Один із найважливіших показників } \\
\text { роботи будівельної організації, що } \\
\text { узагальнює всі сфери її діяльності: } \\
\text { впровадження провідної технології } \\
\text { будівельного виробництва; } \\
\text { покращення організації виробництва } \\
\text { і праці; підвищення рівня механізації } \\
\text { робіт; ступінь використання } \\
\text { виділених матеріально-технічних і } \\
\text { трудових ресурсів }\end{array}$ & & & & & & & + & \\
\hline 5. & $\begin{array}{l}\text { Затрати будівельної організації на } \\
\text { спожиті засоби виробництва і оплату } \\
\text { праці робітників, виражені у } \\
\text { грошовій оцінці }\end{array}$ & & & & + & & & & \\
\hline
\end{tabular}


Висновки і перспективи подальших розвідок. Необхідність удосконалення економічного аналізу фінансових результатів безпосередньо пов'язана зі зростанням ступеня задоволення потреб відповідних користувачів в економічній інформації (інвесторів, замовників, генеральних підрядників, субпідрядників, девелоперів та ін.). Основним джерелом фінансування розвитку господарюючих суб'єктів, ідентифікатором ефективності господарювання є прибуток, що створюється під впливом низки факторів. Опрацьовані дані Державної служби статистики України дають підстави констатувати, що в період 2011-2017рр. будівництво як вид економічної діяльності було збитковим, що особливо актуалізує дослідження факторів динаміки фінансової результативності будівельних підприємств. Починаючи з 2018 р., фінансовим результатом у будівництві в цілому $\epsilon$ прибуток (4414074,1 млн грн).

Беручи до уваги те, що в сучасних умовах господарювання обсяги виконання будівельних робіт значною мірою зростають, чинники динаміки чистого прибутку потребують особливої уваги. Корисними при цьому є результати факторного аналізу, проведення якого уможливлюється будь-яким із трьох прийомів елімінування за умови наявності даних за кілька досліджуваних періодів. Управління прибутком полягає в прийнятті об'єктивних рішень, спрямованих на формування, розподіл та використання прибутку, і відповідно стратегічний розвиток підприємства. Можливість впливати на окреслені фактори дасть змогу нарощувати прибутковість діяльності і спрямовувати наявні ресурси на подальший розвиток будівельного підприємства. Правильний вибір факторної моделі дає змогу відстежити й окреслити саме ті фактори, яким відведено превалюючу роль у формуванні прибутку.

Подальші дослідження будуть спрямовані на ідентифікацію етапів проведення економічного аналізу 3 позиції фінансових результатів будівельних підприємств.

1. Осадча Т. С. Факторний аналіз рентабельності рентного доходу. Економічний аналіз. 2015. Том 22. № 2. С. 108-113. 2. Іщенко Н. А. Факторний аналіз формування прибутку підприємства. Наукові праці КНТУ. Сер. Економічні науки. 2010. Вип. 17. URL: http://www.kntu.kr.ua/doc/zb_17_ekon/stat_17/33.pdf. (дата звернення: 10.01.2020). 3. Мошенський С. 3. Економічний аналіз : підручник / за ред. Ф. Ф. Бутинця. 2-ге вид., доп. і перероб. Житомир : Рута, 2007. 704 с. 4. Єпіфанова І. Ю., Гуменюк В. С. Фактори зростання прибутку підприємства. Молодий вчений. 2016. № 7(34). С. 46-49. 5. Патарідзе-Вишинська М. В. Прибуток підприємств: види, роль та функції. Економіка. Управління. Інновації. 2010. № 1. С. 48-55. 6. Бердар М. М. Фінанси підприємств : навч. посіб. Київ : ЦУЛ, 2010. 352 с. 7. Янковий О. Г., Кошельок Г. В. Фактори формування прибутку підприємства. Вісник соціальноекономічних досліджень. 2011. Вип. 3(43). С. 298-305. 8. Розвиток бухгалтерського 
обліку в контексті узгодження антагоністичних інтересів груп заінтересованих осіб : монографія / І. В.Жиглей, В.І.Кузь, О. А. Лаговська, О. В. Олійник. Чернівці : Технодрук, 2012. 248 с. 9. Ивашковский С. Н. Экономика: микро и макроанализ : учебно-практ. пособ. Москва : Дело, 1999. 360 с. 10. Бляхарчук М. О. Формування облікової політики в системі управління підприємством : дис. ... канд. екон. наук : 08.00.09, Луцький національний технічний університет. 2016. 304 с. 11. Баширов А. А. Учет издержек производства и калькулирования себестоимости в подрядном строительстве. Москва : Финансы и статистика, 1986. 207 с. 12. Волков Н. Г. Бухгалтерский учет в строительстве. Москва : Финансы и статистика, 1990. 240 с. 13. Горбунов А. А. Себестоимость строительства и пути ее снижения. Москва : Стройиздат, 1988. 125 с. 14. Дашковский 3. И. Экономический анализ хозяйственной деятельности строительных организаций. Київ : Будівельник, 1982. 152 с. 15. Дружинин А. В. Снижение себестоимости в строительстве. Київ : Будівельник, 1989. 120 с. 16. Дьячков М. Ф. Анализ хозяйственной деятельности в строительстве : учебник. Москва : Финансы и статистика, 1987. 264 с. 17. Лялин Д.Е. Себестоимость и сметные нормы в строительстве. Москва : Стройиздат, 1988. 208 с. 18. Экономика строительства / под общей ред. И. П. Сытника. Москва : Издательство литературы по строительству, 1970. 19. Методичні рекомендації 3 формування собівартості будівельно-монтажних робіт : затв. наказом М-ва регіонального розвитку та будівництва України від 31.12.2010 р. № 573. URL: https://msmeta.com.ua/file/ Metoduchni\%20 rekomendazii.pdf (дата звернення: 12.01.2020).

\section{REFERENCES:}

1. Osadcha T. S. Faktornyi analiz rentabelnosti rentnoho dokhodu. Ekonomichnyi analiz. 2015. Tom 22. № 2. S. 108-113. 2. Ishchenko N. A. Faktornyi analiz formuvannia prybutku pidpryiemstva. Naukovi pratsi KNTU. Ser. Ekonomichni nauky. 2010. Vyp. 17. URL: http://www.kntu.kr.ua/doc/zb_17_ekon/stat_17/33.pdf. (data zvernennia: 10.01.2020). 3. Moshenskyi S. Z. Ekonomichnyi analiz : pidruchnyk / za red. F. F. Butyntsia. 2-he vyd., dop. i pererob. Zhytomyr : Ruta, 2007. 704 s. 4. Yepifanova I. Yu., Humeniuk V. S. Faktory zrostannia prybutku pidpryiemstva. Molodyi vchenyi. 2016. № 7(34). S. 46-49. 5. Pataridze-Vyshynska M. V. Prybutok pidpryiemstv: vydy, rol ta funktsii. Ekonomika. Upravlinnia. Innovatsii. 2010. № 1. S. 48-55. 6. Berdar M. M. Finansy pidpryiemstv : navch. posib. Kyiv : TsUL, 2010. 352 s. 7. Yankovyi 0. H., Koshelok H. V. Faktory formuvannia prybutku pidpryiemstva. Visnyk sotsialnoekonomichnykh doslidzhen. 2011. Vyp. 3(43). S. 298-305. 8. Rozvytok bukhhalterskoho obliku v konteksti uzghodzhennia antahonistychnykh interesiv hrup zainteresovanykh osib : monohrafiia / I. V. Zhyhlei, V. I. Kuz, O. A. Lahovska, O. V. Oliinyk. Chernivtsi : Tekhnodruk, 2012. 248 s. 9. Ivashkovskii S. N. Ekonomika: mikro i makroanaliz: uchebno-prakt. posob. Moskva : Delo, 1999. 360 s. 10. Bliakharchuk M. O. Formuvannia oblikovoi polityky $v$ systemi upravlinnia pidpryiemstvom : dys. ... kand. ekon. nauk: 08.00.09, Lutskyi natsionalnyi tekhnichnyi universytet. 2016. 304 s. 11. Bashirov A. A. Uchet izderzhek proizvodstva i kalkulirovaniia sebestoimosti $v$ podriadnom stroitelstve. Moskva : Finansy i statistika, 1986. 207 s. 12. Volkov N. H. Bukhhalterskii uchet $v$ stroitelstve. Moskva : Finansy i statistika, 1990. 240 s. 13. Horbunov A. A. Sebestoimost stroitelstva i puti ee snizheniia. Moskva : Stroiizdat, 1988. $125 \mathrm{~s}$. 14. Dashkovskii Z. Y. Ekonomicheskii analiz khoziaistvennoi deiatelnosti stroitelnykh orhanizatsii. Kyiv : Budivelnyk, 1982. 152 s. 15. Druzhinin A. V. Snizhenie sebestoimosti v stroitelstve. Kyiv : Budivelnyk, 1989. 120 s. 16. Diachkov M. F. Analiz khoziaistvennoi 
deiatelnosti $\mathrm{v}$ stroitelstve : uchebnik. Moskva : Finansy i statistika, 1987. $264 \mathrm{~s}$. 17. Lialin D. E. Sebestoimost i smetnye normy v stroitelstve. Moskva : Stroiizdat, 1988. 208 s. 18. Ekonomika stroitelstva / pod obshchei red. I. P. Sytnika. Moskva : Izdatelstvo literatury po stroitelstvu, 1970. 19. Metodychni rekomendatsii z formuvannia sobivartosti budivelno-montazhnykh robit : zatv. nakazom M-va rehionalnoho rozvytku ta budivnytstva Ukrainy vid 31.12.2010 r. № 573. URL: https://msmeta.com.ua/file/ Metoduchni\%20 rekomendazii.pdf (data zvernennia: 12.01.2020).

Pavelko 0. V., Candidate of Economics (Ph.D.), Associate Professor (National University of Water and Environmental Engineering, Rivne)

\section{FACTOR ANALYSIS OF FINANCIAL RESULTS OF CONSTRUCTION ENTERPRISES ACTIVITY: METHODS AND FEATURES OF CONDUCTION}

The essence of factor analysis and its types are investigated in the article. Factor analysis of gross profit and profit of operating activity of «Renome-Eurobud» LLC for the years 2014-2018 is performed. It is established that profit is a factor of development and consequence of any production, the main indicator of successful activity of the enterprise, the financial result of activity of the economic entity. The influence of factors on the resulting indicators is established. The factor analysis of net profit of PE «Rivnespetsbud» for $\mathbf{2 0 1 5 - 2 0 1 8}$ is performed by the method of chain substitutions, the results of factor analysis are identified.

The factors of growth of net profit of construction enterprises are outlined. We propose to distinguish them into the following groups: external (not dependent on the activity of the enterprise) and internal factors (prioritizing the impact on the magnitude of profit), which in turn, it is advisable to classify production and non-production. Production factors are divided into extensive (affecting the size of profit through quantitative changes) and intensive (affecting through qualitative changes).

A critical analysis of the opinions of analysts on the essence of the cost of construction works is carried out. The directions of its minimization are characterized. It is determined that the most common among scientists is the universal definition of the cost of construction works as the actual costs of the construction company, which are associated with the execution of construction works and production of products and services. It is proposed to consider the cost of construction works as a generalized indicator of the efficiency of management of construction enterprises, which involves the inclusion in its composition of the cost of necessary logistical and labor resources, maintenance costs of the control units of separate production units, the costs incurred in the delivery of the customer and facilities, also the cost of construction work performed by subcontractors.

It has been found out that the most important factors for maximizing the profit of construction enterprises are internal factors: increasing the 
volume of construction works while minimizing their cost; improving the quality of construction products; productivity growth and etc.

Keywords: economic analysis; factor analysis; financial results; methods of factor analysis; construction enterprises; profit.

Павелко О. В., к.э.н., доцент

(Национальный университет водного хозяйства и природопользования,

г. Ровно)

\section{АНАЛИЗ ФИНАНСОВЫХ РЕЗУЛЬТАТОВ ДЕЯТЕЛЬНОСТИ СТРОИТЕЛЬНЫХ ПРЕДПРИЯТИЙ: МЕТОДИКА И ОСОБЕННОСТИ ПРОВЕДЕНИЯ}

В статье исследована сущность факторного анализа и его виды. Идентифицированы и проклассифицированы факторы влияния на формирование прибыли строительных предприятий. Выполнен факторный анализ валовой прибыли и прибыли операционной деятельности 000 «Реноме-Еврострой» за 2014-2018 гг. методом цепных подстановок и относительных разниц. Предложены факторные модели и установлено влияние факторов на результирующие показатели. Проведен факторный анализ чистой прибыли 000 «Ровноспецстрой» за 2015-2018 гг. методом цепных подстановок, идентифицированы результаты факторного анализа. Определены факторы роста чистой прибыли строительных компаний. Осуществлен критический анализ мнений ученыХ-аналитиков относительно сущности себестоимости строительно-монтажных работ. Охарактеризованы направления ее минимизации.

Ключевые слова: экономический анализ; факторный анализ; финансовые результаты; методы факторного анализа; строительные предприятия; прибыль. 